\title{
Ripening Associated Red Color Development Masks Sunburn Browning in Apple Peel
}

\author{
Brian Makeredza, Helen Marais, Michael Schmeisser, and Elmi Lötze \\ Department of Horticultural Science, University of Stellenbosch, Private Bag \\ X1, Matieland, 7602, Stellenbosch, South Africa
}

\author{
Willem J. Steyn ${ }^{1}$ \\ HORTGRO Science, P.O. Box 12789, Die Boord 7613, South Africa
}

Additional index words. anthocyanin, sunburn browning, sunburn necrosis, masking, red color

\begin{abstract}
Red color development toward harvest may conceal superficial blemishes such as sunburn browning in apple peel. Masking of sunburn may result in the underestimation of sunburn incidence in full red and blushed cultivars and may result in inaccurate assessments of sunburn susceptibility of various cultivars. However, anthocyanin accumulation may potentially also increase sunburn by decreasing the albedo and thereby increasing the fruit surface temperature (FST). Conversely, it has been proposed that anthocyanins may protect peel against photothermal stress. We assessed the effect of anthocyanin accumulation on the visible sunburn incidence in two trials. In the first trial, hue angle, blush coverage, sunburn incidence, and sunburn severity were assessed on fully exposed apples of the green cultivars, Granny Smith and Golden Delicious, as well as the blushed cultivars, Royal Gala, Fuji, Braeburn, and Cripps' Pink, and the full red cultivar Topred, a month before harvest and again at harvest. Increases in sunburn toward harvest were greater in green than in red and blushed cultivars. Accumulation of anthocyanins seemed to decrease the conspicuousness of sunburn browning, which is a superficial form of sunburn while sunburn necrosis, which manifests as sunken black spots, was not masked by anthocyanins. In the second trial, 'Granny Smith', 'Fuji', and 'Cripps' Pink' apples with moderate sunburn browning, sunburn necrosis, or no sunburn were tagged 1 month before the expected harvest date. Sunburn browning was apparent and significantly increased in severity in 'Granny Smith' while the severity of visible sunburn browning symptoms decreased in 'Fuji'. Sunburn severity increased at the same level in the control and sunburn browning 'Cripps' Pink' fruit. Measurement of maximal photochemical efficiency of the originally undamaged apples and the sunburn browning treatment indicated comparable damage levels in the peel of the sunburn browning treatment in all three cultivars. No masking of sunburn necrosis occurred. Our data thus provide clear evidence that anthocyanin accumulation masks sunburn browning in blushed and red cultivars, but does not seem to increase the susceptibility or protect these cultivars from sunburn damage. The incidence of sunburn browning is likely to be underestimated in red and blushed cultivars, with compounding effects on comparative studies of sunburn susceptibility between cultivars and sunburn physiology.
\end{abstract}

The Mediterranean-type climate apple production areas of the Western Cape of South Africa are subject to high irradiation and high summer temperatures. These environmental conditions are conducive to the development of sunburn (Schrader et al.,

\footnotetext{
Received for publication 13 Feb. 2015. Accepted for publication 1 Apr. 2015.

This article is based upon the work supported by the THRIP program of the National Department of Trade and Industry and the South African Apple and Pear Producers' Association. Any opinions, findings and conclusions or recommendations expressed in this material are those of the authors and do not necessarily reflect the views of the National Research Foundation.

This article forms part of a thesis submitted by Brian Makeredza in fulfilling an MSc. Agric degree requirement.

${ }^{1}$ To whom reprint requests should be addressed; e-mail wiehann@hortgro.co.za.
}

2003; Van den Ende, 1999), resulting in the downgrading of fruit and lower income for producers.

Almost all cultivars are susceptible to sunburn, although some are seemingly more sensitive than others. Of the cultivars grown in South Africa, Granny Smith seems to be particularly sensitive to sunburn, Golden Delicious, Braeburn, Fuji, and Delicious are less sensitive while Cripps' Pink is least sensitive (Racsko and Schrader, 2012 and references therein). Schrader et al. (2001) demonstrated that threshold temperature for sunburn development is cultivar dependent and ranged from $47{ }^{\circ} \mathrm{C}$ to $51{ }^{\circ} \mathrm{C}$. 'Delicious' and 'Jonagold' had the highest and lowest thresholds, respectively, while 'Gala', 'Fuji' 'Braeburn', and 'Golden Delicious' were intermediate. This differential susceptibility could be a function of the physiochemical properties of fruit peel (Wünsche et al., 2004), but may also relate to indirect factors that may modulate the occurrence of sunburn. This could include factors such as when during the season the fruit ripens, the tree architecture and bearing habit, and the accumulation of anthocyanin in the peel toward harvest that may mask the visible symptoms of sunburn (Evans, 2004; Racsko and Schrader, 2012; Schrader et al., 2001). Masking of sunburn by anthocyanin in blushed and red cultivars may result in the misconception of cultivar susceptibility to sunburn.

As anthocyanins mostly accumulate in the epidermal and hypodermal tissue of apple peel (Gross, 1987), red color development may conceal the two superficial forms of sunburn viz sunburn browning and photo-oxidative bleaching. These two types of sunburn entail the loss of chlorophyll and accumulation of phenolic compounds and carotenoids (in the case of browning) in the hypodermis (Felicetti and Schrader, 2009; Wünsche et al., 2001). Sunburn necrosis, however, is not hidden by red color development, as it results in the death of epidermal and sub-epidermal tissue, causing the formation of sunken, brown to black necrotic spots on the affected fruit area (Schrader et al., 2003). The ability of apple fruit to produce anthocyanin during ripening differs among cultivars (Curry, 1997; Saure, 1990). The logical inference is that the more intense the pigmentation, the less severe the sunburn browning and bleaching on an affected fruit is likely to appear, irrespective of the underlying damage to the peel.

Although red color development may mask underlying sunburn symptoms, some sources argue that the accumulation of additional pigment should increase sensitivity to sunburn. Woolf and Ferguson (2000) reasoned that dark pigmented fruit would attain higher temperatures than green pigmented fruit under the same conditions. Anthocyanin accumulation makes the fruit darker, reducing the reflective capacity (albedo) (Evans 2004; Schroeder, 1965; Smart and Sinclair, 1976). The resultant increased radiant heating due to low albedo, increases FST (Smart and Sinclair, 1976). Considering the involvement of high temperature in the development of sunburn (Schrader et al., 2008), increased FSTs should increase the risk of sunburn. In agreement, Hetherington (1997) reported increased sunburn in purple compared with green mango cultivars. However, contrary to the above, Li and Cheng (2009) found that anthocyanins in the shaded peel of red 'Anjou' pears made it more tolerant to photothermal stress (high light and high temperature).

By acting as a superficial light screen attenuating irradiation impinging on chloroplasts, anthocyanins have been shown to reduce short-term photoinhibition (Gould et al., 1995; Hada et al., 2003). Rabinowitch et al. (1983) argued that green pepper and cucumber cultivars are more predisposed to sunburn development compared with red cultivars, because their fruit peel contains more chlorophyll, which plays a role in the photo-oxidative processes of sunburn.

To fully understand the differential sunburn susceptibility between different apple cultivars, a comparative progressive assessment 
of sunburn development between these cultivars is necessary. The objective of this study was to investigate the effect of red color development on sunburn incidence and severity in red, blushed, and green apple cultivars. We hypothesized that accumulation of anthocyanin toward harvest in blushed and red cultivars would mask sunburn browning resulting in a lower perceived incidence and severity of sunburn at harvest compared with nonblushed cultivars and a resultant underestimation of the sunburn sensitivity of these cultivars. Anthocyanin accumulation should, however, not affect the incidence of sunburn necrosis.

\section{Materials and Methods}

Trial 1. This experiment was carried out at De Rust Estate (3410' S; $19^{\circ} 4^{\prime} \mathrm{E}$ ) in Elgin, South Africa during the 2009-10 season. Seven apple cultivars were used viz green Granny Smith and Golden Delicious, blushed Royal Gala, Fuji, Braeburn, and Cripps' Pink, and the full red Topred.

'Royal Gala', 'Granny Smith', and 'Fuji' were all on M793 rootstock. The remaining cultivars were all on seedling rootstock. 'Granny Smith' and 'Fuji' were planted in 2000 at a tree spacing of $4 \mathrm{~m} \times 1.5 \mathrm{~m}$, while 'Royal Gala' was planted in 1987 at a tree spacing of $4 \mathrm{~m} \times 2 \mathrm{~m}$. 'Topred' and 'Golden Delicious' were planted in 1984, whereas 'Cripps' Pink' and 'Braeburn' were planted in 1991 and all at a tree spacing of $4 \mathrm{~m} \times 2 \mathrm{~m}$. 'Fuji', 'Granny Smith', and 'Cripps' Pink' had a northeast by southwest row orientation, while 'Royal Gala', 'Braeburn', 'Golden Delicious', and 'Topred' had an east to west orientation. All trees were trained to a central leader.

For each cultivar, four 30 -fruit plots were selected at random within an orchard on the northern or north-western side of the row. Fruit that were fully sun-exposed, but showed no prior sunburn were tagged and marked on 12 Jan. 2010 for repeated evaluation.

Sunburn incidence and sunburn severity were evaluated a month before expected commercial harvest and at commercial harvest on the same fruit. Sunburn severity was assessed using a $0-5$ scale developed by Schrader and McFerson (Schrader et al., 2003), where 0 represented no sunburn and five, sunburn necrosis. At harvest, sunburn severity was assessed using the same Schrader and McFerson scale and a 'Granny Smith' sunburn evaluation chart (Deciduous Fruit Board Set A33) for all cultivars. Assessments for a month before harvest were made on 12 Jan. ('Royal Gala'), 3 Feb. ('Topred'), 11 Feb. ('Golden Delicious'), 25 Feb. ('Fuji' and 'Braeburn'), 6 Mar. ('Granny Smith'), and 19 Mar. ('Cripps' Pink') 2010. Fruit were harvested on 11 Feb. ('Royal Gala'), 06 Mar. ('Golden Delicious' and 'Topred'), 30 Mar. ('Fuji'), 31 Mar. ('Braeburn'), 9 Apr. ('Granny Smith'), and 23 Apr. ('Cripps' Pink') 2010.

At harvest, sunburnt fruit were classified according to sunburn category, viz sunburn browning, sunburn necrosis, and photooxidative bleaching (Schrader et al., 2003). Each category was expressed as a percentage of the total sunburn. Sunburn incidence was expressed as the proportion of fruit that showed any sunburn symptoms out of the total fruit.

Hue angle and blush coverage were used as fruit color parameters. Blush coverage was assessed visually at harvest. Hue angle was assessed a month before harvest and at harvest on the reddest position, or for green cultivars midway between the calyx and stem end on the sun-exposed side of the fruit, using a portable colorimeter (CR-400; Minolta Co Ltd, Tokyo, Japan).

Since the cultivars are planted in different orchards, the data were not suited for analysis of variance. Hence, variable means for each cultivar as well as the calculated average means for green (Granny Smith and Golden Delicious) as well as full red and blushed cultivars (Royal Gala, Topred, Braeburn, Fuji, and Cripps' Pink) are provided with standard errors.

Trial 2. The experiment was conducted on the cultivars Granny Smith, Fuji, and Cripps' Pink in commercial orchards on the farm Oak Valley Estate near Grabouw $\left(34^{\circ} 09^{\prime} \mathrm{S} ; 1^{\circ} 02^{\prime}\right.$ E) in the Western Cape, South Africa during the 2013-14 season.

About 1 month before the expected harvest dates of the three cultivars, 25 sunexposed apples that had no sunburn damage, 25 apples that had sunburn damage corresponding to a sunburn damage value of 2 on the aforementioned 'Granny Smith' sunburn evaluation chart, and 25 apples that had sunburn necrosis were tagged as the control, sunburn browning, and sunburn necrosis treatments, respectively. 'Fuji' and 'Granny Smith' fruit were tagged on 7 Mar. 2014 while 'Cripps' Pink' fruit were tagged on 18 Mar. 2014. 'Granny Smith' and 'Fuji' were harvested on 31 Mar. 2014 whilst 'Cripps' Pink' was harvested on 22 Apr. 2014.

After harvest, apples of the control (no prior sunburn) and sunburn browning treatments were again assessed according to the 'Granny Smith' sunburn chart. The color of the control and sunburn browning treatments was measured using a colorimeter (CR-400; Minolta Co Ltd., Tokyo, Japan). Some of the apples of the sunburn browning treatment (one fruit each in 'Granny Smith' and 'Fuji', and three fruit in 'Cripps' Pink') developed sunburn necrosis and were excluded from the colorimeter measurements. The lightness $(\mathrm{L})$, chroma $(\mathrm{C})$, and hue angle $(\mathrm{H})$ as measured by the colorimeter were recorded at the greenest ('Granny Smith') or reddest ('Fuji' and 'Cripps' Pink') position of fruit showing no sunburn symptoms and in the middle of the sunburn spot for the fruit showing sunburn browning. The color of the 'Fuji' apples, excluding those with sunburn necrosis, was also classified using a 'Fuji' color chart [Color Chart Set A. 45, Unifruco (Pty) Ltd.]. The 'Fuji' color chart ranged from one to 12 with one being well colored and bright red, and 12 being colored insufficiently with little red pigmentation. Photos of representative samples of each treatment were taken and are presented in Figure 1.

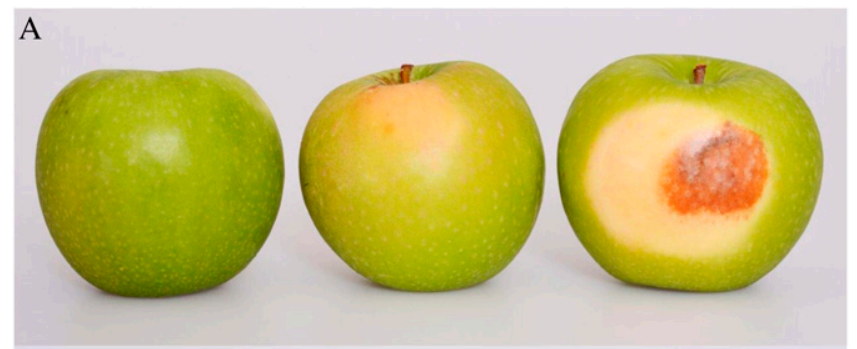

B
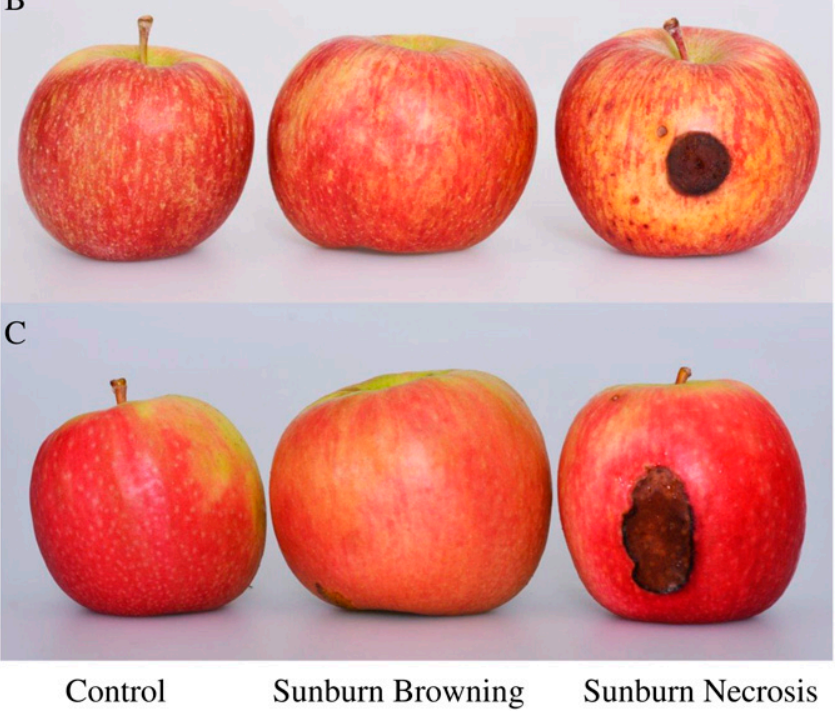

Fig. 1. Representative samples of (A) 'Granny Smith', (B) 'Fuji', and (C) 'Cripps' Pink' at harvest that either had no sunburn (on the left), sunburn browning (middle), or sunburn necrosis (on the right) when tagged about a month before harvest in the 2013-14 season. 
The maximal photochemical efficiency $\left(F_{\mathrm{v}} / F_{\mathrm{m}}\right)$ of all apples, excluding those with sunburn necrosis, was measured using a pulsemodulated fluorimeter (FMS2; Hansatech Instruments Ltd, Norfolk, England). $F_{\mathrm{v}} / F_{\mathrm{m}}$ was recorded at the greenest ('Granny Smith') or reddest ('Fuji' and 'Cripps' Pink') position of fruit showing no sunburn symptoms and in the middle of the sunburn spot for the fruit showing sunburn browning. Fruits were always dark-adapted for $30 \mathrm{~min}$ at $20^{\circ} \mathrm{C}$ before measurement of fluorescence. To determine $F_{\mathrm{v}} / F_{\mathrm{m}}$, the minimal yield of fluorescence $\left(F_{\mathrm{o}}\right)$ was measured making use of weakmodulating light unable to induce photosynthesis. A saturating light pulse $(10,800$ $\mu \mathrm{mol} \cdot \mathrm{m}^{-2} \cdot \mathrm{s}^{-1}$ PPFD at the end of the fiber optic cable for $0.7 \mathrm{~s}$ ) was then used to attain maximal yield of fluorescence, $F_{\mathrm{m}}$. Variable fluorescence, $F_{\mathrm{v}}$, was calculated as $F_{\mathrm{m}}-F_{\mathrm{o}}$.

The data were analyzed according to a completely randomized design. Cultivars were not compared statistically.

\section{Results}

Trial 1. Sunburn incidence increased toward harvest in tagged fruit of all seven apple cultivars (Table 1). Sunburn incidence did not differ significantly between the green cultivars Golden Delicious and Granny Smith at harvest. However, for the red and blushed cultivars, Cripps' Pink and Topred had higher sunburn incidence than Fuji, Braeburn, and Royal Gala a month before harvest. At harvest, 'Cripps' Pink' and 'Topred' had higher sunburn incidence than 'Braeburn' and 'Royal Gala', while 'Fuji' had the lowest. Large increases in sunburn incidence were noted in 'Golden Delicious' and 'Granny Smith', while 'Topred', 'Fuji', and 'Cripps' Pink' showed the smallest increases. In general, green cultivars showed a greater increase in sunburn incidence in the month before harvest than red and blushed cultivars (Table 1). While red color development in the month before harvest seems to correspond to a smaller increase in sunburn, the incidence of necrosis did not seem to relate to fruit color (Table 1). The smaller increase of sunburn in blushed and red cultivars is thus largely due to a smaller increase in sunburn browning, considering that sunburn bleaching was negligible. Sunburn severity in 'Fuji' and 'Cripps' Pink', which had low sunburn incidence, did not differ significantly from 'Braeburn', which had the highest sunburn browning severity at harvest (Table 2).

The severity of sunburn a month before harvest and at harvest did not seem to relate to fruit color. However, toward harvest, sunburn increased more in severity in green compared with red and blushed cultivars (Table 2). In all cultivars, sunburn browning was the most predominant sunburn type, followed by sunburn necrosis. Sunburn bleaching was almost negligible (Table 1).

Using the Schrader and McFerson chart for sunburn severity assessment, sunburn browning and bleaching for all cultivars did not seem to differ. However, using the rigorous 'Granny Smith' chart with a wider scale and more subtle differences between grades, sunburn severity became amplified. 'Braeburn' and 'Cripps' Pink' had significantly higher sunburn browning and bleaching severity than 'Royal Gala' and 'Topred'. 'Fuji' did not differ significantly with either of the two extremes (Table 2). For the nonblushed cultivars, 'Granny Smith' had higher sunburn severity than 'Golden Delicious'.

Trial 2. Sunburn severity as per the 'Granny Smith' sunburn chart increased in both the control and sunburn browning treatment in 'Granny Smith' and 'Cripps' Pink' (Table 3 ). In contrast, the sunburn severity of the 'Fuji' control increased, but decreased for the sunburn browning treatment. The change in sunburn severity between tagging and harvest was significantly greater for the sunburn browning treatment compared with the control in 'Granny Smith' but the difference was not significant in 'Cripps Pink' (Table 3). All fruit with sunburn necrosis when tagged remained so - there was no masking of sunburn necrosis or change to a less severe sunburn type.

$F_{\mathrm{v}} / F_{\mathrm{m}}$ values at harvest were significantly lower for the sunburn browning compared with the control treatment in all three cultivars (Table 4). The lightness value was higher and chroma and hue angle lower for the sunburn browning compared with the control treatment in 'Granny Smith' fruit (Table 4). 'Cripps Pink' treatments did not differ significantly in color (Table 4). The 'Fuji' sunburn browning treatment was lighter and had a higher chroma, but the treatments did not differ in

Table 1. Sunburn incidence 1 month before and at harvest as well as the sunburn type distribution for sunburnt fruit and as percentage of all tagged fruit (within parenthesis) at harvest for different apple cultivars at De Rust Estate during the 2009-10 season. Values are means \pm SE.

\begin{tabular}{|c|c|c|c|c|c|c|}
\hline Cultivar & $\begin{array}{l}\text { Sunburn incidence } \\
\text { before harvest (\%) }\end{array}$ & $\begin{array}{l}\text { Sunburn incidence } \\
\text { at harvest }(\%)\end{array}$ & $\begin{array}{l}\text { Change in sunburn } \\
\text { incidence }(\%)\end{array}$ & $\begin{array}{c}\text { Sunburn } \\
\text { browning (\%) }\end{array}$ & $\begin{array}{c}\text { Sunburn } \\
\text { necrosis (\%) }\end{array}$ & $\begin{array}{c}\text { Sunburn } \\
\text { bleaching }(\%)\end{array}$ \\
\hline G. Delicious & $46 \pm 7.4$ & $69 \pm 5.9$ & $23 \pm 5.2$ & $95 \pm 5(66)$ & $0(0)$ & $5 \pm 5(4)$ \\
\hline G. Smith & $38 \pm 2.7$ & $57 \pm 6.7$ & $19 \pm 8.7$ & $70 \pm 5(40)$ & $24 \pm 8(14)$ & $7 \pm 7(3)$ \\
\hline \multicolumn{7}{|c|}{ Blushed/Red cultivars } \\
\hline Royal Gala & $15 \pm 2.8$ & $26 \pm 3.2$ & $11 \pm 2.9$ & $63 \pm 5(16)$ & $29 \pm 10(8)$ & $13 \pm 10(3)$ \\
\hline Topred & $34 \pm 6.4$ & $38 \pm 4.1$ & $4 \pm 3.1$ & $89 \pm 7(34)$ & $11 \pm 7(4)$ & $0(0)$ \\
\hline Cripps' Pink & $40 \pm 5$ & $46 \pm 6.7$ & $6 \pm 2.1$ & $82 \pm 7(38)$ & $13 \pm 5(6)$ & $8 \pm 5(4)$ \\
\hline Mean & $24 \pm 5$ & $31 \pm 5$ & $7 \pm 2$ & $81 \pm 5(26)$ & $18 \pm 3(5)$ & $5 \pm 3(2)$ \\
\hline
\end{tabular}

Table 2. Development of red color and sunburn severity during the last month before harvest and at harvest for different apple cultivars at De Rust Estate during the $2009-10$ season. Values are means \pm SE.

\begin{tabular}{|c|c|c|c|c|c|c|c|c|}
\hline \multirow[b]{2}{*}{ Cultivar } & \multicolumn{2}{|c|}{ Hue angle $\left({ }^{\circ}\right)$} & \multirow{2}{*}{$\begin{array}{c}\text { Decrease in } \\
\text { hue angle }\left({ }^{\circ}\right)\end{array}$} & \multirow{2}{*}{$\begin{array}{c}\text { Blush } \\
\text { coverage }(\%)\end{array}$} & \multicolumn{2}{|c|}{ Sunburn severity ${ }^{2}$} & \multirow{2}{*}{$\begin{array}{l}\text { Change in } \\
\text { severity }\end{array}$} & \multirow{2}{*}{$\begin{array}{c}\text { Granny } \\
\text { Smith chart }{ }^{y}\end{array}$} \\
\hline & Before harvest & At harvest & & & Before harvest & $\overline{\text { At harvest }}$ & & \\
\hline \multicolumn{9}{|l|}{ Green cultivars } \\
\hline G. Delicious & $115 \pm 0.2$ & $112 \pm 0.2$ & $3 \pm 0.2$ & - & $0.4 \pm 0.1$ & $2.0 \pm 0.1$ & $1.6 \pm 0.1$ & $3.2 \pm 0.2$ \\
\hline Mean & $116 \pm 0.5$ & $114 \pm 2$ & $2 \pm 2$ & & $0.8 \pm 0.4$ & $2.3 \pm 0.3$ & $1.6 \pm 0.1$ & $4.1 \pm 2.0$ \\
\hline \multicolumn{9}{|c|}{ Blushed/Red cultivars } \\
\hline R. Gala & $69 \pm 2.8$ & $48 \pm 3.4$ & $21 \pm 4$ & $29 \pm 2$ & $0.7 \pm 0.2$ & $1.7 \pm 0.1$ & $1.0 \pm 0.2$ & $4.1 \pm 0.2$ \\
\hline Topred & $81 \pm 1.7$ & $34 \pm 2.0$ & $47 \pm 2$ & 100 & $1.3 \pm 0.2$ & $1.9 \pm 0.1$ & $0.6 \pm 0.2$ & $4.0 \pm 0.2$ \\
\hline C. Pink & $78 \pm 0.9$ & $36 \pm 2.1$ & $42 \pm 2$ & $35 \pm 2$ & $1.3 \pm 0.1$ & $2.3 \pm 0.2$ & $1.0 \pm 0.1$ & $4.6 \pm 0.2$ \\
\hline Mean & $78 \pm 2$ & $46 \pm 5$ & $32 \pm 5$ & $46 \pm 13$ & $1.0 \pm 0.1$ & $2.1 \pm 0.1$ & $1.1 \pm 0.2$ & $4.4 \pm 0.1$ \\
\hline
\end{tabular}

${ }^{\mathrm{z}} 0-4$ sunburn browning and bleaching score with 0 having no sunburn and 4 being the most severe sunburn.

${ }^{\mathrm{y}} 1-8$ score, with one having the least severe sunburn. 
Table 3. Sunburn severity of 'Granny Smith', 'Fuji', and 'Cripps' Pink' apples at harvest in 2014 and the change in sunburn severity since tagging of fruit that had no sunburn (control), sunburn browning or sunburn necrosis 1 month before harvest.

\begin{tabular}{|c|c|c|}
\hline & Sunburn severity ${ }^{z}$ & $\begin{array}{c}\text { Change in sunburn } \\
\text { severity }^{z}\end{array}$ \\
\hline \multicolumn{3}{|l|}{ Granny Smith } \\
\hline Control & $0.12 \mathrm{c}^{\mathrm{y}}$ & $0.12 \mathrm{~b}$ \\
\hline Sunburn Browning & $2.84 \mathrm{~b}$ & $0.84 \mathrm{a}$ \\
\hline Sunburn Necrosis & $6.00 \mathrm{a}$ & - \\
\hline$P$ value & $<0.0001$ & 0.0005 \\
\hline \multicolumn{3}{|l|}{ Fuji } \\
\hline Control & $0.16 \mathrm{c}$ & $0.16 \mathrm{a}$ \\
\hline Sunburn Browning & $1.52 \mathrm{~b}$ & $-0.48 \mathrm{~b}$ \\
\hline Sunburn Necrosis & $6.00 \mathrm{a}$ & - \\
\hline$P$ value & $<0.0001$ & 0.0158 \\
\hline \multicolumn{3}{|l|}{ Cripps' Pink } \\
\hline Control & $0.54 \mathrm{c}$ & $0.44^{\mathrm{NS}}$ \\
\hline Sunburn Browning & $2.34 \mathrm{~b}$ & 0.34 \\
\hline Sunburn Necrosis & $6.00 \mathrm{a}$ & \\
\hline$P$ value & $<0.0001$ & 0.8424 \\
\hline
\end{tabular}

${ }^{\text {z }}$ Sunburn severity according to the 'Granny Smith' sunburn chart $(1=$ no sunburn, $2-5=$ increasing severity of sunburn browning, and $6=$ sunburn necrosis).

${ }^{\mathrm{y}}$ Means with different letters differ significantly at $P<0.05$.

${ }^{\mathrm{NS}}$ Nonsignificant.

Table 4. Visual appearance and maximal photochemical efficiency $\left(F_{\mathrm{v}} / F_{\mathrm{m}}\right)$ at harvest of 'Granny Smith', 'Fuji', and 'Cripps' Pink' apples that had no sunburn (control) or sunburn browning when tagged about 1 month before harvest during the 2013-14 season.

\begin{tabular}{|c|c|c|c|c|c|}
\hline & $F_{\mathrm{v}} / F_{\mathrm{m}}$ & Lightness & Chroma & Hue $\left(^{\circ}\right)$ & Color chart $^{2}$ \\
\hline \multicolumn{6}{|l|}{ Granny Smith } \\
\hline Control & $0.784 \mathrm{a}^{\mathrm{y}}$ & $59.26 \mathrm{~b}$ & $45.67 \mathrm{a}$ & $113.49 \mathrm{a}$ & \\
\hline Browning & $0.628 \mathrm{~b}$ & $65.99 \mathrm{a}$ & $41.31 \mathrm{~b}$ & $85.37 \mathrm{~b}$ & \\
\hline$P$ value & 0.0013 & 0.0176 & 0.0207 & $<0.0001$ & \\
\hline \multicolumn{6}{|l|}{ Fuji } \\
\hline Control & $0.750 \mathrm{a}$ & $43.26 \mathrm{~b}$ & $32.59 \mathrm{~b}$ & $41.51^{\mathrm{NS}}$ & $2.44^{\mathrm{NS}}$ \\
\hline Browning & $0.516 \mathrm{~b}$ & $47.81 \mathrm{a}$ & $39.70 \mathrm{a}$ & 39.79 & 2.56 \\
\hline$P$ value & $<0.0001$ & 0.0094 & $<0.0001$ & 0.5645 & 0.7625 \\
\hline \multicolumn{6}{|l|}{ Cripps' Pink } \\
\hline Control & $0.701 \mathrm{a}$ & $51.49^{\mathrm{NS}}$ & $40.45^{\mathrm{NS}}$ & $39.31^{\mathrm{NS}}$ & - \\
\hline Browning & $0.483 \mathrm{~b}$ & 54.76 & 39.21 & 36.15 & - \\
\hline$P$ value & $<0.0001$ & 0.1304 & 0.6324 & 0.5449 & \\
\hline
\end{tabular}

z'Fuji' color chart $(1=$ full red, $12=$ green $)$.

${ }^{\mathrm{y}}$ Means with different letters differ significantly at $P<0.05$.

${ }^{\text {NSNonsignificant. }}$

hue angle (redness). No color chart difference was observed between control and sunburn browning treatments in 'Fuji' (Table 4). The photographs of representative fruit of the three cultivars show a lower perceived sunburn damage in the sunburn browning treatment in red 'Fuji' and 'Cripps' Pink' compared with the green 'Granny Smith' (Fig. 1).

\section{Discussion}

We set out to show that anthocyanin accumulation toward harvest masks sunburn browning in blushed and red cultivars. At the same time, we wanted to show that anthocyanin accumulation does not increase sunburn in blushed and red cultivars. High irradiance induces sunburn at FSTs exceeding $48{ }^{\circ} \mathrm{C}$, whereas sunburn necrosis will develop at temperatures exceeding $52{ }^{\circ} \mathrm{C}$ (Schrader et al., 2001, 2008). It follows that anthocyanin might increase sunburn by increasing the albedo and thereby the heat load of the fruit (Hetherington, 1997; Smart and Sinclair, 1976). Finally, in addition to masking, lower incidences of sunburn in blushed and red masked the symptoms of sunburn (Schrader et al., 2001).

If the less severe sunburn is masked, the remaining visible sunburn that is averaged would be more severe, contributing to higher sunburn severity. This could explain why blushed cultivars such as Fuji and Cripps' Pink had a lower sunburn incidence than the nonblushed cultivars, but did not differ significantly from them with regard to sunburn severity. For the nonblushed cultivars, sunburn symptoms are observed against a pale background. This is mostly chlorophyll, the actual pigment acted upon in the photooxidative processes of sunburn (Rabinowitch et al., 1983). Therefore, the slightest sunburn development is easily noticeable and this amounts to high sunburn incidence among these fruit. Sunburn browning and bleaching generally were not easily distinguished into discrete grades for red and blushed cultivars. To become easily noticeable, sunburn symptoms have to become necrotic in blushed cultivars. In 'Golden Delicious', sunburn browning and bleaching severity could also have been lessened by attainment of a yellow color during ripening due to chlorophyll degradation with concomitant carotenoid synthesis (Gorski and Creasy, 1977; Knee, 1971). Therefore, apart from differences in red color development in the fruit peel, our findings also seem to suggest the importance of differential sunburn susceptibility among cultivars, which could be a function of other inherent physiochemical properties of fruit peel (Wünsche et al., 2004). Of course, various cultural and managerial differences between the orchards in which the cultivars were planted as well as differences in climate during the ripening periods of the cultivars may affect both the sunburn sensitivity as well as the ability to develop red color. For example, Fouché et al. (2010) found sunburn to affect more fruit on the northern side of east-west planted rows whereas, there was no difference in sunburn incidence between western and eastern sides of north-south planted rows. This relates to the maximum zenith angle of $79^{\circ}$ that the sun reaches on the southern hemisphere summer solstice causing more sunlight exposure and a greater heat load on fruit on the northern sides of eastwest rows. All the fruit in our first trial were collected from the northern or northwestern sides of east-west and southwest-northeast tree rows and thus row orientation was unlikely to affect our results. It seems from the data that innate cultivar differences played a larger role in the relative changes in sunburn incidence that occurred in the month before harvest. The data of our first trial are also consistent with the results of the second trial, which employed a different approach to study masking.

In our second trial, the severity of sunburn browning increased more in sunburn browning fruit of 'Granny Smith' than in control fruit, increased in control fruit of 'Fuji' but decreased in the sunburn browning treatment, and increased to the same extent in both treatments in 'Cripps' Pink'. Sunburn browning symptoms 
were clearly visible in 'Granny Smith', but were obscured in 'Cripps' Pink' and especially 'Fuji' by the overlaying red pigmentation. Again, no masking of sunburn necrosis occurred. The lack of an effect of anthocyanin accumulation on the incidence of sunburn necrosis while reducing sunburn browning in full red and blushed cultivars suggests that anthocyanins mask superficial sunburn symptoms rather than provide protection against sunburn. However, anthocyanins present in the peel during thermal cell death are not expected to mask the necrotic black spots that develop, nor provide protection against sunburn necrosis. Masking of sunburn necrosis by anthocyanins in apple and pear peel is not possible as anthocyanins are readily degraded under temperatures that cause sunburn necrosis (Steyn et al., 2004) and of course dead cells in the peel are unable to synthesize anthocyanins. Sunburn necrosis can be induced at the same temperature $\left(52^{\circ} \mathrm{C}\right)$ in the dark or in the light (Racsko and Schrader, 2012) and therefore anthocyanins are unlikely to protect apple peel against sunburn necrosis. However, the decrease in sunburn browning, which is an adaptive response to photothermal stress (Racsko and Schrader, 2012), can be attributed to either photoprotection or masking. Fruit that displayed sunburn browning at the time of tagging were probably more exposed to sunburn-inducing factors, i.e., high irradiance and a resultant high heat load, compared with the control fruit that had no sunburn. Considering that exposure levels would not change much in the month before harvest, the greater increase in sunburn severity of 'Granny Smith' sunburn browning fruit compared with control fruit from tagging to harvest makes perfect sense. The apparent reduction in sunburn severity for the 'Fuji' sunburn browning fruit can only be ascribed to masking by anthocyanin or to actual alleviation of the sunburn browning symptoms.

The actual photochemical efficiency $\left(F_{\mathrm{v}} / F_{\mathrm{m}}\right)$ of photosystem II provides an indication of the health of the photosynthetic system. The unstressed $F_{\mathrm{v}} / F_{\mathrm{m}}$ value for most plants is 0.83 while a value of 0.6 and below is indicative of photodamage (Maxwell and Johnson, 2000; Ritchie, 2006). The $F_{\mathrm{v}} / F_{\mathrm{m}}$ values obtained for the control fruit indicated that the control treatments of all the cultivars had minimal photodamage while fruit of the sunburn browning treatment showed significant damage. In other words, the peel of 'Fuji' and 'Cripps' Pink' fruit of the sunburn browning treatment showed significant photodamage, indicative of sunburn, despite the decrease of sunburn symptoms in 'Fuji'. This supports the observation that sunburn browning is being masked in the blushed and red cultivars and suggests that anthocyanin accumulation does not have a curative effect on sunburn browning.

In conclusion, red color development masks sunburn browning and sunburn bleaching in blushed and red apple cultivars. The accumulation of anthocyanin in these cultivars does not seem to increase the sunburn susceptibility of fruit and also does not seem to cure sunburn development (although it hides the symptoms). However, our data do not allow us to discard the possibility that photoprotective ability of anthocyanin may decrease photodamage and resultant sunburn symptomology development in blushed and red apple cultivars.

Since, sunburn browning is the most predominant form of sunburn, red color development, either through masking and also possibly by providing photoproctection, can substantially reduce the proportion of fruit culled due to sunburn in blushed and red apple cultivars. Sunburn browning present before anthocyanin synthesis largely goes unnoticed in dark red and black Japanese plum cultivars and the same may apply for various anthocyanin-rich fruits. Contreras et al. (2008) acknowledged the difficulty of detecting less severe sunburn at harvest in blushed apple cultivars, while red color development precludes the use of background color as maturity index in full red peaches and nectarines (Crisosto, 1994). The downside of masking is that undetected sunburn may increase variability in fruit quality on the shelf (Woolf and Ferguson, 2000) and might potentially also affect storability (Wünsche et al., 2001). In addition, results on the differential sensitivity of cultivars to sunburn should be interpreted with caution since the visible presence of sunburn does not necessarily relate to the actual cultivar sensitivity. The masking of sunburn browning in blushed and red cultivars will result in the underestimation of the susceptibility of these cultivars to sunburn compared with green and yellow cultivars, a fact which should be kept in mind when breeding for sunburn resistance, conducting comparative studies of sunburn susceptibility between cultivars and when studying sunburn physiology.

\section{Literature Cited}

Contreras, C., J.P. Zoffoli, J.A. Alcalde, and M. Ayala 2008. Evolution of sunburn in 'Granny Smith' apples during storage. Cien. Inv. Agr. 35:113122.

Curry, E.A. 1997. Temperatures for optimum anthocyanin accumulation in apple tissue. J. Hort. Sci. 72:723-729.

Crisosto, C.H. 1994. Stone fruit maturity indices: A descriptive review. Postharv. News Info. 5:65-68.

Evans, R.G. 2004. Energy balance of apples under evaporative cooling. Trans. Amer. Soc. Agr. Eng. 47:1029-1037.

Felicetti, D.A. and L.E. Schrader. 2009. Changes in pigment concentrations associated with sunburn browning of five apple cultivars. I. Chlorophylls and carotenoids. Plant Sci. 176:78-83.

Fouché, J.R., S.C. Roberts, S.J.E. Midgley, and W.J. Steyn. 2010. Peel color and blemishes in 'Granny Smith' apples in relation to canopy light environment. HortScience 45:899-905.

Gorski, P.M. and L.L. Creasy. 1977. Colour development in Golden Delicious apples. J. Amer. Soc. Hort. Sci. 102:73-75.

Gould, K.S., D.N. Kuhn, D.W. Lee, and S.F. Oberbauer. 1995. Why leaves are sometimes red. Nature 378:241-242.

Gross, J. 1987. Pigments in fruit. Acad. Press, London.

Hada, H., J. Hidema, M. Maekawa, and T. Kumagai. 2003. Higher amounts of anthocyanins and
UV-absorbing compounds effectively lowered CPD photorepair in purple rice (Oryza sativa L.). Plant Cell Environ. 26:1691-1701.

Hetherington, S.E. 1997. Profiling photosynthetic competence in mango fruit. J. Hort. Sci. 72:755763.

Knee, M. 1971. Anthocyanin, carotenoid and chlorophyll changes in the peel of Cox's Orange Pippin apples during ripening on and off the tree. J. Expt. Bot. 23:184-196.

Li, P. and L. Cheng. 2009. The elevated anthocyanin level in the shaded peel of 'Anjou' pear enhances its tolerance to high temperature under high light. Plant Sci. 177:418-426.

Maxwell, K. and G.N. Johnson. 2000. Chlorophyll fluorescence-a practical guide. J. Expt. Bot. 51:659-668.

Pietrini, F. and A. Massacci. 1998. Leaf anthocyanin content changes in Zea mays L. grown at low temperature: Significance for the relationship between quantum yield of PSII and the apparent quantum yield of $\mathrm{CO}_{2}$ assimilation. Photosynth. Res. 58:213-219.

Rabinowitch, H.D., M. Friedman, and B. Ben-David. 1983. Sunscald damage in attached and detached pepper and cucumber fruits at various stages of maturity. Sci. Hort. 19:9-18.

Racsko, J. and L.E. Schrader. 2012. Sunburn of apple fruit: Historical background, recent advances and future perspectives. Crit. Rev. Plant Sci. 31:455504.

Ritchie, G.A. 2006. Chlorophyll fluorescence: What is it and what do the numbers mean? In: L.E. Riley, R.K. Dumroese, and T.D. Landis (Technical coordinators). 2006. National Proceedings: Forest and Conservation Nursery Associations-2005. Proc. RMRS-P-43. Fort Collins, CO: U.S. Department of Agriculture, Forest Service, Rocky Mountain Research Station. 160 p.

Saure, M.C. 1990. External control of anthocyanin formation in apple. Sci. Hort. 42:181-218.

Schrader, L.E., J. Sun, J. Zhang, D. Felicetti, and J. Tian. 2008. Heat and light-induced apple skin disorders: Causes and prevention. Acta Hort. 772:51-58.

Schrader, L.E., J. Zhang, and W.K. Duplaga. 2001. Two types of sunburn in apple caused by high fruit surface (peel) temperature. Plant Health Prog. 1 Dec. 2010. <http://hort.tfrec.wsu.edu/ les/Temperature.pdf $>$.

Schrader, L.E., J. Zhang, and J. Sunday. 2003. Environmental stress that cause sunburn of apple. Acta Hort. 618:397-405.

Schroeder, C.A. 1965. Temperature relationships in fruit tissues under extreme conditions. Proc. Amer. Soc. Hort. Sci. 87:199-203.

Smart, R.E. and T.R. Sinclair. 1976. Solar heating of grape berries and other spherical fruit. Agr. Meteorol. 17:241-259.

Steyn, W.J., D.M. Holcroft, S.J.E. Wand, and G. Jacobs. 2004. Anthocyanin degradation in detached pome fruit with reference to preharvest red color loss and pigmentation patterns of blushed and fully red pears. J. Amer. Soc. Hort. Sci. 129:13-19.

Van den Ende, B. 1999. Sunburn management. Compact Fruit Tree. 32:13-14.

Woolf, A.B. and I.B. Ferguson. 2000. Postharvest responses to high fruit temperatures in the field. Postharvest Biol. Technol. 21:7-20.

Wünsche, J.N., D.H. Greer, J.W. Palmer, A. Lang, and T. McGhie. 2001. Sunburn: The cost of a high light environment. Acta Hort. 557:349-356.

Wünsche, J.N., T. McGhie, J. Bowen, I. Ferguson, and A. Woolf. 2004. Sunburn on applescauses and control mechanisms. Acta Hort. 636:631-636. 